\title{
Indicative nutrient supplying capacity and chemical properties of coir dust, coco husk and other coir dust-based materials
}

\author{
Ma. Celia M. Raquepo ${ }^{1}$, Carmelita D. Pabustan ${ }^{2}$, and Severino S. Magat ${ }^{3}$
}

\begin{abstract}
The variability of the nutrient contents and chemical properties of coir dust or coco peat derived from coconut husk in different locations was noted. Coir dust is a good supplementary source of $\mathrm{N}, \mathrm{P}, \mathrm{K}$ and $\mathrm{Cl}$, including micronutrients ( $\mathrm{B}, \mathrm{Cu}, \mathrm{Fe}, \mathrm{Zn}, \mathrm{Mn}$ ). The coir dust acidity ranges from $\mathrm{pH} 5.2-7.0$, and EC from $0.10-1.67 \mathrm{~ms} / \mathrm{cm}$ based from: fresh (1 month), 3 - 5 months, and 1 year open-field piling (storage). Higher contents of nutrients $\mathrm{K}, \mathrm{Cl}$, and $\mathrm{Fe}$ of coir dust under coastal area was noted; but contents of N, P, Ca, Mg, S, B, Zn, Mn and Cu were found similar in coastal and inland areas. Under rainfall in open-field piling, $\mathrm{Cl}$ dropped to $<0.25 \%$ at $3-5$ months and $<0.12 \%$ in a year's time period. Moreover, a significant reduction of $<0.30$ and $<0.15$ $\mathrm{EC}(\mathrm{m} / \mathrm{cm})$ in mentioned periods were indicated, respectively.

Generally, as compared with other nut components, coco husk and the coir dust did not differ in nutrient contents and chemical properties. As composting material, either alone or in mixes, coco peat showed to be a supplementary source of $\mathrm{P}, \mathrm{K}$ and $\mathrm{Cl}$. NPK ratio was 2:1:2; and organic carbon content ranged from $6.34-12.07 \%$
\end{abstract}

Key words: Coconut, coco husk, coir dust, coco peat, macronutrient, micronutrient and chloride.

\footnotetext{
${ }^{1}$ Senior Science Research Specialist, Plant and Soil Analysis Division, Agricultural Research Management Department, Research, Development and Extension Branch, Philippine Coconut Authority, Quezon City 1107, Philippines.

${ }^{2}$ Division Chief III, Plant and Soil Analysis Division, Agricultural Research Management Department, Research, Development and Extension Branch, Philippine Coconut Authority, Quezon City 1107, Philippines.

${ }^{3}$ Career Scientist IV, Department Manager III, Agricultural Research Management Department, Research, Development and Extension Branch, Philippine Coconut Authority, Quezon City 1107, Philippines.
} 


\section{Introduction}

In the past, coir dust or coco peat, the material left over from the husk after the extraction of the fiber was considered a farm or industrial waste. For the last 10 years, many studies and experiments were conducted tapping coir dust as potential medium for growing ornamental plants. These studies highlighted positive possibilities and good overall plant growth and propagation results. Recently, its use as a soil conditioner and slowrelease fertilizer, rooting and plant media for agricultural and horticultural uses, and mulch in nurseries among others, resulted in profound interest in this material, nationally and globally, not to exclude the Asia and Pacific regions.

The desired qualities of coir dust in relation to the nutrient contents and some chemical properties, $\mathrm{pH}$ and EC, vary according to its utilization. The nutrient contents, $\mathrm{pH}$ and $\mathrm{EC}$ are highly variable depending on area classification (coastal and inland), age of open-field piling and farming practices.

Much consciousness has to be taken for the production of coir dust to reduce quality problem. The preparation of chemical properties standards in addition to physical and phytosanitary standards in the horticultural market will help meet certain minimum quality requirements specific for that purpose.

\section{Materials and methods}

The Plant Tissue Analysis Laboratory (PTAL) of the Philippine Coconut Authority (PCA), Diliman, Quezon City, Metro Manila conducted the chemical analysis of coir dust, coconut husk, chicken manure, coir-based organic compost (fertilizer) and organic compost (fertilizer) samples submitted to the laboratory according to the following sources:

Coir dust samples: A total of eight (8) coir dust samples from different locations - three (3) from Mauban / Lucban, Quezon; three (3) from Davao City and two (2) from Zamboanga City (Philippines) were submitted during 1995-2002. The samples were obtained from open-field piling (1 month - 1 year of piling).
Coconut husk samples: A total of seven (7) coconut husk samples from Davao Research Center (DRC) were submitted during 1989-1990.

Chicken manure samples: A total of five (5) samples from various sources were submitted in 1999. An organic compost fertilizer sample from Urban Gardening Project claimed to contain 30\% chicken manure and $40 \%$ coir dust was submitted in 2003.

Coir-based organic compost (fertilizer) samples: A total of seven (7) samples from Mulanay, Quezon, Iligan City and Davao City (Philippines) were submitted in 2003.

\section{Preparation of samples}

All coir dust and coconut husk samples submitted to the laboratory were further dried in an oven at $60^{\circ} \mathrm{C}$ overnight, then ground in a Wiley Mill with stainless steel blades, passed through $1 \mathrm{~mm}$ sieve, mixed thoroughly and stored in a plastic bag. Organic fertilizer samples like chicken manure and compost fertilizers were transferred to a clean plastic sheet, the lumpy portions crushed and mixed thoroughly. The samples were reduced to a quantity sufficient for analysis by quartering, mixed and kept in an airtight plastic container.

\section{Chemical analysis}

Nutrient contents of the samples were analyzed for $\mathrm{N}, \mathrm{P}, \mathrm{K}, \mathrm{Ca}, \mathrm{Mg}, \mathrm{Na}, \mathrm{Cl}, \mathrm{S}, \mathrm{B}, \mathrm{Fe}, \mathrm{Cu}$, $\mathrm{Mn}, \mathrm{Zn}$ and other chemical parameters such as organic $\mathrm{C}, \mathrm{EC}, \mathrm{pH}$ and moisture were determined using standard procedures used for plant and fertilizer analysis.

\section{Statistical analysis}

Statistical indices such as mean, standard deviation and range were used to measure the variability of data.

\section{Results and discussion}

\section{General variability of chemical properties of coir dust}

Selected chemical properties of coir dust; coconut husk and other relevant materials were determined at the Plant Tissue Analysis Laboratory (PTAL) of the Philippine Coconut Authority (PCA), Diliman, Quezon City, Metro Manila. 
Table 1 and Figures $1 \mathrm{a}$ and $1 \mathrm{~b}$ show the nutrient supplying capacities and other chemical properties of coir dust irrespective of sources and age of piling. It is noted that practically all nutrients and other chemical properties do not vary much except for $\mathrm{Fe}$ as indicated in the

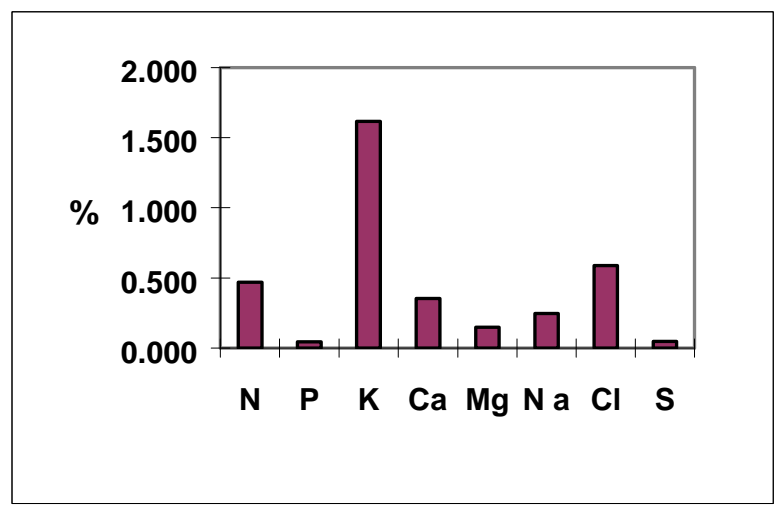

Fig. 1a. Variability of several macronutrients of coir dust calculated standard deviation of 681.2. It is revealed that coir dust is good source of NPK and other micronutrients. $\mathrm{PH}$ ranges from 5.2 to as high as 7.0 and EC from 0.10 to 1.67. Still, these values revealed an insignificant spread as shown in the standard deviations calculated.

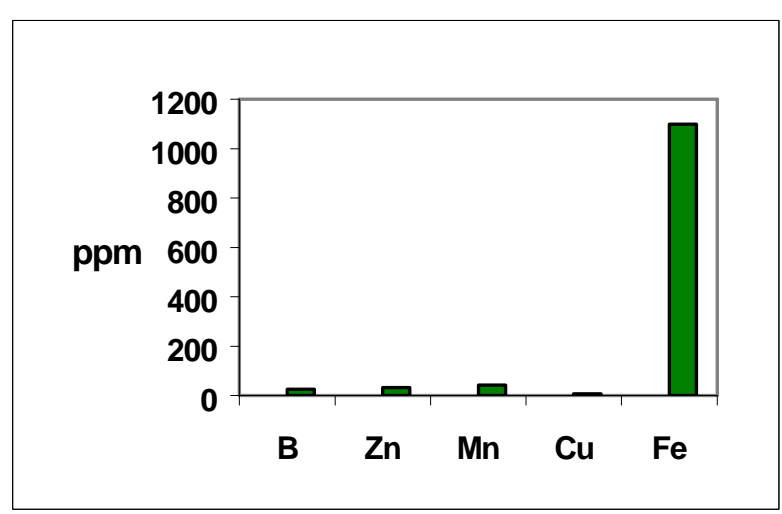

Fig. 1b. Variability of micronutrients of coir dust

Table 1. Nutrient content and chemical properties of coir dust as analyzed by PTAL (1995-2002)

\begin{tabular}{|c|c|c|c|c|c|c|c|c|c|c|}
\hline \multirow{2}{*}{$\begin{array}{l}\text { Nutrients / } \\
\text { Chemical } \\
\text { properties } \\
\end{array}$} & \multicolumn{8}{|c|}{ Source $^{a}$} & \multirow{2}{*}{ Mean } & \multirow{2}{*}{$\begin{array}{l}\text { Standard } \\
\text { Deviation }\end{array}$} \\
\hline & 1 & 2 & 3 & 4 & 5 & 6 & 7 & 8 & & \\
\hline $\mathrm{N}(\%)$ & 0.398 & 0.478 & 0.605 & 0.523 & 0.548 & 0.373 & 0.398 & 0.463 & 0.467 & 0.063 \\
\hline $\mathrm{P}(\%)$ & 0.057 & 0.037 & 0.011 & 0.054 & 0.022 & 0.072 & 0.031 & 0.055 & 0.045 & 0.017 \\
\hline $\mathrm{K}(\%)$ & 0.997 & 0.990 & 1.548 & 1.655 & 1.105 & 2.724 & 1.283 & 1.746 & 1.615 & 0.549 \\
\hline $\mathrm{Ca}(\%)$ & 0.179 & 0.171 & 0.260 & 0.349 & 0.332 & 0.156 & 0.377 & 0.690 & 0.352 & 0.171 \\
\hline $\operatorname{Mg}(\%)$ & 0.136 & 0.302 & 0.167 & 0.139 & 0.165 & 0.126 & 0.124 & 0.133 & 0.148 & 0.028 \\
\hline $\mathrm{Na}(\%)$ & 0.554 & 0.359 & 0.215 & 0.188 & 0.142 & 0.094 & 0.318 & 0.400 & 0.245 & 0.110 \\
\hline $\mathrm{Cl}(\%)$ & 1.341 & 0.583 & 0.113 & 0.640 & 0.114 & 1.536 & 0.182 & 0.393 & 0.591 & 0.472 \\
\hline $\mathrm{S}(\%)$ & 0.032 & 0.044 & 0.104 & 0.038 & 0.052 & 0.048 & 0.050 & 0.052 & 0.050 & 0.007 \\
\hline B (ppm) & 21.1 & 22.6 & 21.3 & 25.6 & 20.8 & 23.7 & 23.8 & 29.5 & 24.2 & 2.836 \\
\hline $\mathrm{Zn}(\mathrm{ppm})$ & 19.5 & 15.5 & 13.7 & 51.8 & 63.3 & 17.0 & 19.2 & 20.8 & 31.4 & 18.856 \\
\hline $\mathrm{Mn}(\mathrm{ppm})$ & 62.2 & 56.1 & 24.4 & 10.2 & 85.8 & 9.4 & 45.5 & 56.6 & 42.5 & 26.610 \\
\hline $\mathrm{Cu}(\mathrm{ppm})$ & 9.7 & 7.3 & 6.7 & 4.6 & 7.0 & 5.1 & 7.5 & 9.2 & 6.9 & 1.591 \\
\hline $\mathrm{Fe}(\mathrm{ppm})$ & 353.0 & 453.7 & 281.2 & 646.2 & 235.5 & 532.2 & 1253.6 & 1450.7 & 1099.5 & 681.288 \\
\hline $\mathrm{PH}$ & 5.8 & 5.5 & 5.2 & 6.9 & 6.6 & 5.8 & 7.0 & 5.6 & 6.3 & 0.576 \\
\hline $\operatorname{Ec}(\mathrm{m} / \mathrm{cm})$ & 1.67 & 0.30 & 0.19 & 1.11 & 0.34 & 1.06 & 0.10 & 0.12 & 0.58 & 0.414 \\
\hline
\end{tabular}

a1= Mauban, Quezon; 2 = Mauban/ Lucban, Quezon; 3= Mauban Quezon; 4= San Ramon, Zamboanga City, 5= Davao City, $6=$ Davao City, $7=$ Davao City, $8=$ Davao City 


\section{Nutrient contents in relation to age of open- field piling}

There were 3 periods of piling observed, namely: 1) 1 month - almost fresh; 2) 3-5 months; and 3) 1 year old. The samples were piled under open-field conditions. Table 2 shows the nutrient contents of coir dust, $\mathrm{EC}$ and $\mathrm{pH}$ of the material at different ages of open-storage. Data were not taken from same source, i.e., the 3 - 5 months and one year were obtained from different locations in the country resulting in the higher contents of coir dust $\mathrm{N}, \mathrm{P}, \mathrm{Ca}, \mathrm{Mg}, \mathrm{Mn}$, $\mathrm{Cu}$ and $\mathrm{Fe}$ at 3 - 5 months old compared to either 1 month (almost fresh) or the one-year ones (Figure 2b). Such observations may be attributed to the soil fertility conditions of palms used as sources of coir dust tested.

An earlier study on the chemical properties of coir dust (coco peat) from different coconut producing areas (Davao, San Pablo and Laguna) clearly indicated the wide variability in several nutrients like $\mathrm{N}, \mathrm{P}, \mathrm{K}, \mathrm{Mg}, \mathrm{Cl}$ and $\mathrm{Na}$ (Evans and Stamps, undated). Levels of $\mathrm{K}$ in coir dust ranged from 172 to $1150 \mathrm{ppm}$, while that of $\mathrm{Cl}$ from 250 to $800 \mathrm{ppm}$. Likewise, it was revealed by them that the coir dust micronutrients $(\mathrm{B}, \mathrm{Zn}$ $\mathrm{Cu}, \mathrm{Fe}$ and $\mathrm{Mn}$ ) differed.

Table 2. Relationship of nutrient contents and chemical properties of coir dust and period of opening field piling (mean values)

\begin{tabular}{|l|r|r|r|}
\hline \multirow{2}{*}{$\begin{array}{c}\text { Nutrients/Chemical } \\
\text { properties }\end{array}$} & \multicolumn{3}{|c|}{ Period of open-field piling } \\
\cline { 2 - 4 } & $\begin{array}{c}\text { Fresh ( 1 } \\
\text { month) }\end{array}$ & $\begin{array}{c}\text { 3-5 } \\
\text { months }\end{array}$ & \multicolumn{1}{c|}{ 1 year } \\
\hline $\mathrm{N}(\%)$ & 0.431 & 1.208 & 0.605 \\
\hline $\mathrm{P}(\%)$ & 0.061 & 0.492 & 0.011 \\
\hline $\mathrm{K}(\%)$ & 1.792 & 0.418 & 0.548 \\
\hline $\mathrm{Ca}(\%)$ & 0.228 & 0.341 & 0.260 \\
\hline $\mathrm{Mg}(\%)$ & 0.134 & 0.315 & 0.167 \\
\hline $\mathrm{Na}(\%)$ & 0.279 & 0.265 & 0.215 \\
\hline $\mathrm{Cl}(\%)$ & 1.172 & 0.226 & 0.113 \\
\hline $\mathrm{S}(\%)$ & 0.039 & 0.048 & 0.104 \\
\hline $\mathrm{B}(\mathrm{ppm})$ & 23.5 & 23.9 & 21.3 \\
\hline $\mathrm{Zn}(\mathrm{ppm})$ & 29.4 & 28.8 & 13.7 \\
\hline $\mathrm{Mn}(\mathrm{ppm})$ & 27.3 & 63.7 & 24.4 \\
\hline $\mathrm{Cu}(\mathrm{ppm})$ & 6.5 & 7.7 & 6.7 \\
\hline $\mathrm{Fe}(\mathrm{ppm})$ & 510.5 & 1927.4 & 281.2 \\
\hline $\mathrm{EC}(\mathrm{m} / \mathrm{cm})$ & 1.28 & 0.32 & 0.14 \\
\hline $\mathrm{PH}$ & 6.2 & 5.9 & 5.2 \\
\hline
\end{tabular}

However, the lower levels of $\mathrm{Cl}$ and $\mathrm{Na}$, and EC (an index of soluble salts) of coir dust under open-piled conditions at 3 - 5 months and oneyear periods compared to the fresh coir dust were noted (Figures 2a). Evans and Stamps (undated) reported that $\mathrm{Cl}$ level of coir dust dropped below $100 \mathrm{ppm}$ within 14 days after planting of indicator plants and placement in the greenhouse, and with the top watering; the $\mathrm{Cl}$ in the growing substrate was significantly leached out.

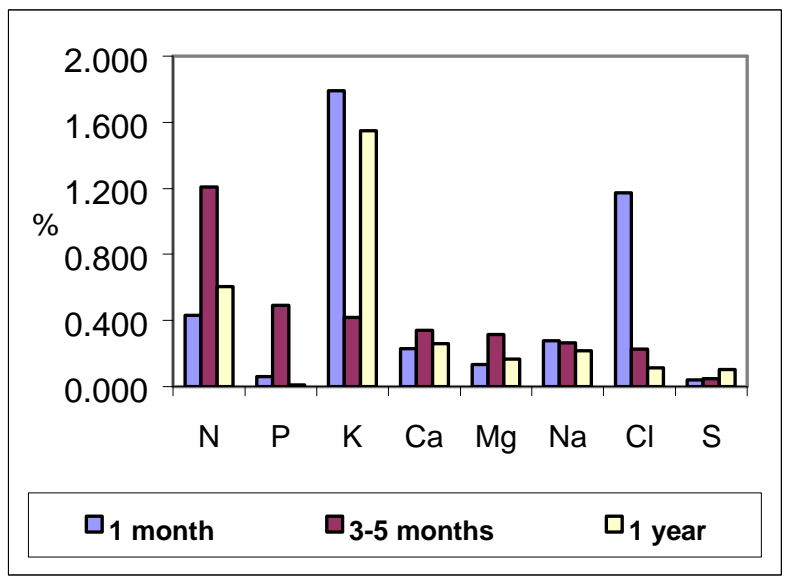

Fig. 2a. Variation of nutrient contents (macronutrients) and time of open-field piling of coir dust

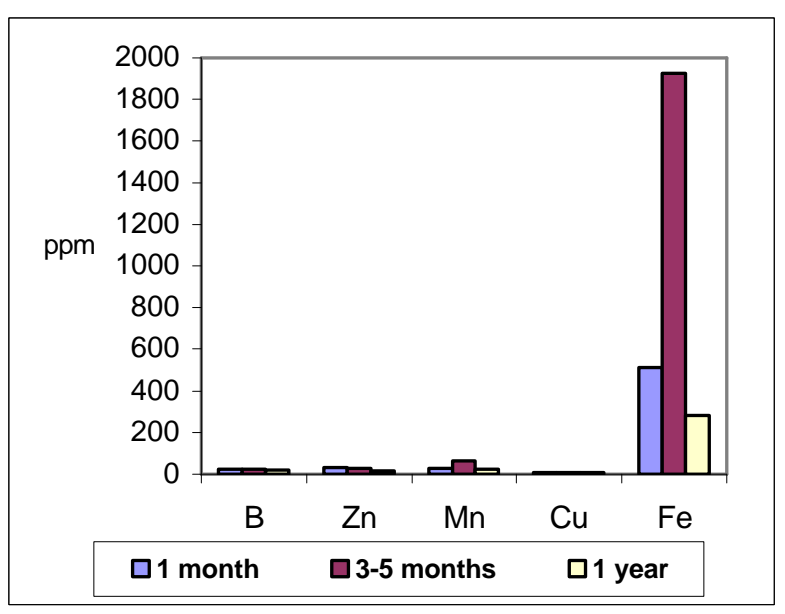

Fig. 2b. Variation of nutrient contents (macronutrients) and time of open-field piling of coir dust 
Influence of coastal/inland location of coir dust source

Figures $3 \mathrm{a}$ and $3 \mathrm{~b}$ show the profile of nutrients of coir dust for inland and coastal areas. High values of $\mathrm{K}, \mathrm{Cl}$ and $\mathrm{Fe}$ of coir dust are noted for coastal region. But for others as $\mathrm{N}, \mathrm{P}$, $\mathrm{Ca}, \mathrm{Mg}, \mathrm{S}, \mathrm{B}, \mathrm{Zn}, \mathrm{Mn}$ and $\mathrm{Cu}$ nutrient contents are similar for inland and coastal sources.

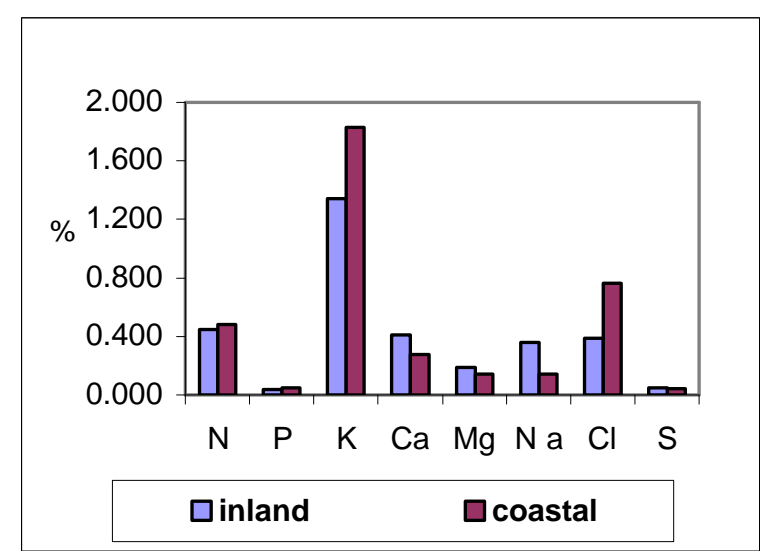

Fig. 3a. Variation of nutrient contents (macronutrients) of coir dust in relation to coastal/inland location

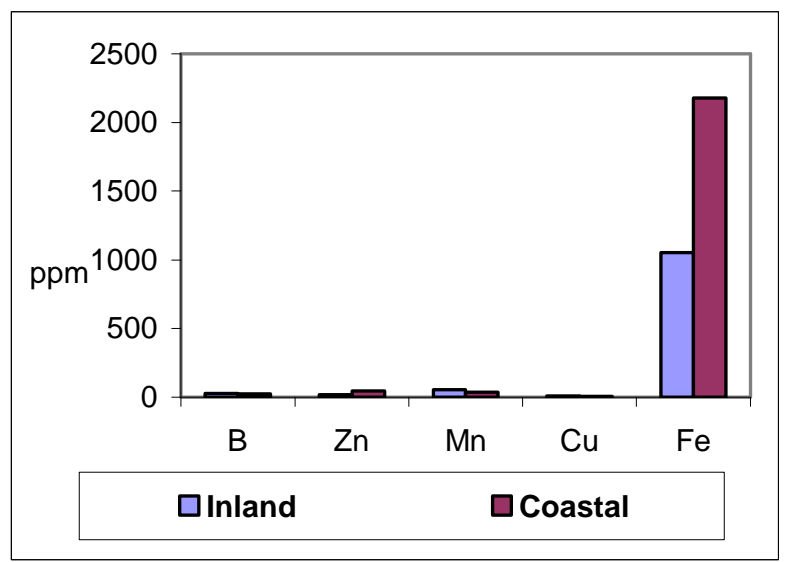

Fig. 3b. Variation of nutrient contents (macronutrients) of coir dust in relation to coastal/inland location

\section{Nutrient contents of coco husk}

Generally, coconut husk consists of only $30 \%$ usable fibers and coir dust comprises about $70 \%$ of it. The long fibers of coir are extracted from husks and are used in the manufacture of brushes, automobile seat and mattress stuffing, twine and other products. The short fibers $(2 \mathrm{~mm}$ or less) and dust (pith), which are left behind, comprise the coconut coir dust.

Table 3 shows the nutrient contents of coco husk and coco peat. The nutrient contents and chemical properties of these two nut components were not significantly different.

Table 3. Nutrients of coco husk vs. coir dust

\begin{tabular}{|l|r|r|r|}
\hline $\begin{array}{c}\text { Nutrient } \\
\text { content }\end{array}$ & $\begin{array}{c}\text { Coco } \\
\text { husk }\end{array}$ & Coir dust & $\begin{array}{c}\text { Standard } \\
\text { deviation }\end{array}$ \\
\hline $\mathrm{N}(\%)$ & 0.403 & 0.467 & 0.045 \\
\hline $\mathrm{P}(\%)$ & 0.020 & 0.045 & 0.018 \\
\hline $\mathrm{K}(\%)$ & 2.121 & 1.615 & 0.359 \\
\hline $\mathrm{Ca}(\%)$ & 0.215 & 0.352 & 0.097 \\
\hline $\mathrm{Mg}(\%)$ & 0.114 & 0.148 & 0.024 \\
\hline $\mathrm{Na}(\%)$ & 0.095 & 0.245 & 0.106 \\
\hline $\mathrm{Cl}(\%)$ & 0.915 & 0.591 & 0.229 \\
\hline $\mathrm{S}(\%)$ & 0.021 & 0.050 & 0.020 \\
\hline $\mathrm{B}(\mathrm{ppm})$ & 21.4 & 24.2 & 1.986 \\
\hline
\end{tabular}

Nutrient profile of coir-based organic (compost) fertilizer

Coir dust, being environment-friendly, easy to handle, and as it contains significant concentrations of mineral nutrients particularly $\mathrm{P}$, $\mathrm{K}, \mathrm{Cl}$ and desired physical qualities, it is a good material for composting, either alone or in mixes, to be used as organic fertilizer. Table 4 and Figure 5 show the NPK and organic carbon contents of coir-based organic compost fertilizer with varying mixes e.g. hog manure and chicken manure. The low organic carbon content (range: 6.337-12.073\%) may be an indication of the degree of decomposition. The NPK ratio shown in Table 4 is $2: 1: 2$. 
Table 4. NPK and organic carbon contents of coirbased organic compost fertilizer

\begin{tabular}{|l|c|c|c|}
\hline $\begin{array}{c}\text { Nutrients/Chemical } \\
\text { properties }\end{array}$ & Mean ${ }^{\text {a }}$ & Range & $\begin{array}{c}\text { Standard } \\
\text { deviation }\end{array}$ \\
\hline $\mathrm{N}(\%)$ & 2.15 & $0.88-3.23$ & 0.88 \\
\hline $\mathrm{P}(\%)$ & 1.35 & $0.71-2.50$ & 0.56 \\
\hline $\mathrm{K}(\%)$ & 2.27 & $0.83-4.75$ & 1.16 \\
\hline Organic Carbon $^{\mathrm{b}}(\%)$ & 8.61 & $6.34-12.07$ & 2.11 \\
\hline
\end{tabular}

${ }^{a}$ average of 8 samples

${ }^{\mathrm{b}}$ colorimetric method

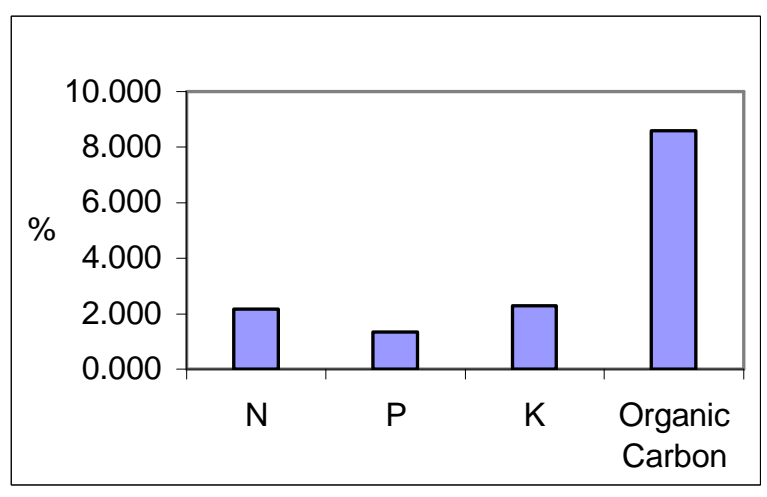

Fig. 5. NPK and organic carbon profile of coir-based organic fertilizer

\section{Comparative nutrient content profile of coir dust, chicken manure and compost}

Usually, animal manures e.g. chicken, cow, goat and hog are used as fertilizers for vegetables, field crops and fruit / industrial tree crops. Chicken manure, which has a fairly stable content of mineral nutrients together with coir dust, is a good material for composting. Table 5 shows a comparative nutrient contents of coir dust, chicken manure and a compost-based manure.

It appears that most macronutrient supplying capacities of coir dust-based manure (fertilizer) are significantly improved by the addition of another organic fertilizer like chicken manure. This confirms claims that coir dust serves more as a soil conditioner, improving the plant growth and yield by enhancing the fertilizer use efficiency through better soil fertility and soil structure, as well as providing a balanced crop nutrition for optimized yields and quality of the plant harvests.

Table 5. Comparative nutrient composition of coir dust, chicken manure and compost

\begin{tabular}{|l|r|r|r|r|}
\hline $\begin{array}{c}\text { Nutrients / } \\
\text { Chemical } \\
\text { properties }\end{array}$ & $\begin{array}{c}\text { Coir } \\
\text { dust }^{\mathrm{b}}\end{array}$ & $\begin{array}{c}\text { Chicken }_{\text {manure }^{\mathrm{c}}} \\
\mathrm{N}(\%)\end{array}$ & $\begin{array}{c}\text { Coir } \\
\text { dust- } \\
\text { based } \\
\text { manure }\end{array}$ & $\begin{array}{c}\text { Compost }^{\mathrm{d}} \\
\text { manure }^{\mathrm{e}}\end{array}$ \\
\hline $\mathrm{P}(\%)$ & 0.463 & 2.100 & 2.150 & 3.560 \\
\hline $\mathrm{K}(\%)$ & 1.615 & 3.100 & 2.270 & 0.670 \\
\hline $\mathrm{Ca}(\%)$ & 0.352 & 5.340 & - & 3.500 \\
\hline $\mathrm{Mg}(\%)$ & 0.148 & 1.950 & - & 1.640 \\
\hline $\mathrm{Na}(\%)$ & 0.245 & 0.970 & - & 0.559 \\
\hline $\mathrm{Cl}(\%)$ & 0.591 & 0.640 & - & 0.810 \\
\hline $\mathrm{S}(\%)$ & 0.050 & 0.090 & - & - \\
\hline $\mathrm{B}(\mathrm{ppm})$ & 24.2 & 45.0 & - & 22.5 \\
\hline $\mathrm{Zn}(\mathrm{ppm})$ & 31.4 & 589.0 & - & 328.9 \\
\hline $\mathrm{Mn}(\mathrm{ppm})$ & 42.5 & 1711.0 & - & 815.2 \\
\hline $\mathrm{Cu}(\mathrm{ppm})$ & 6.9 & 116.0 & - & 62.1 \\
\hline $\mathrm{Fe}(\mathrm{ppm})$ & 1099. & 27620.0 & - & 15590.0 \\
\hline $\begin{array}{l}\text { Organic C } \\
(\%)\end{array}$ & - & 5.1 & 8.6 & 7.8 \\
\hline $\mathrm{EC}(\mathrm{ms} / \mathrm{cm})$ & 0.68 & - & - & - \\
\hline Acidity (pH) & 6.3 & - & - & 5.3 \\
\hline
\end{tabular}

${ }^{a}$ Sample (coir dust, $40 \%$; chicken manure, $30 \%$; garden soil, $30 \%$ from Urban Gardening Project (UGP), Bagong Buhay, Project 4, Quezon City

${ }^{b}$ Average of 8 samples (various sources) analyzed, PCA-Plant Tissue Analysis Laboratory, Quezon City

${ }^{c}$ Average of 5 samples (various sources), PCA- Plant Tissue Analysis Laboratory, Quezon City

d Average of 8 samples (various sources), PCA- Plant Tissue Analysis Laboratory, Quezon City

${ }^{\mathrm{e}}$ Sample (claimed as Organic Compost Fertilizer) submitted by PCA-Trade and Market Branch (TMB), 14 July 2003 to PCA-Plant Tissue Analysis Laboratory, Quezon City

\section{Conclusion}

The nutrient contents and chemical properties of coconut husk-based materials particularly coir dust or coco peat are apparently influenced by the location or sources of the materials. Contents of nutrients $\mathrm{N}, \mathrm{P}, \mathrm{Ca}, \mathrm{Mg}, \mathrm{S}$, $\mathrm{B}, \mathrm{Zn}, \mathrm{Mn}$ and $\mathrm{Cu}$ in the coir dust are noted to be similar in coastal and inland sources, except for $\mathrm{K}, \mathrm{Cl}$, and $\mathrm{Fe}$ that are higher in coastal areas. In 
relation to age of open-field piling, $\mathrm{EC}$ and $\mathrm{Cl}$ levels decreased with time i.e., 3 - 5 months and one year, as a result of rainfall leaching under open-field piling. This observation is vital in the propagation of different crops / ornamentals as their tolerance to salts and/or $\mathrm{Cl}$ is important as generally, an EC $<1.0 \mathrm{~ms} / \mathrm{cm}$ and $\mathrm{Cl}$ concentration lower than $100 \mathrm{ppm}$ are acceptable for growth of plants.

For the use of organic (compost) fertilizer, coir dust or coconut husk is a good material for composting, either alone or mixes, as it contains significant concentrations of mineral nutrients particularly $\mathrm{P}, \mathrm{K}, \mathrm{Cl}$ and other desirable physical properties. This confirms claims that coir dust serves as a soil conditioner, improving the plant growth and yield by enhancing the fertilizer use efficiency through better soil fertility and structure, as well as providing a balanced crop nutrition for optimized yields and quality of the plant growth.

Coir dust, with respect to its field and horticultural application, is indeed a potential source of plant nutrients particularly $\mathrm{N}, \mathrm{P}, \mathrm{K}, \mathrm{Cl}$ and micronutrients, $\mathrm{B}, \mathrm{Fe}, \mathrm{Mn}, \mathrm{Zn}$ and $\mathrm{Fe}$, which are generally beneficial to plants. Its macronutrient and micronutrient supplying capacities can be significantly improved by the addition of dried chicken manure.

\section{References}

Evans, M.R. and Stamps, R.H. undated. Development of Philippine Coir Dust as a Production Substrate for the Horticultural Market - A Final Report. United States Agency for International Development, Washington D.C., Chemonics International Consulting, Washington, D.C. Agribusiness Systems Assistance Program. Metro Manila, Philippines, 46 pp.

Magat, S.S. 1998. Determining Nutritional Status and Fertilizer Recommendation for Coconut. 87. ISSN-0116-8681. R \& D Technical Report No. 5. Agricultural Research and Development Branch. Philippine Coconut
Authority, Diliman, Quezon City, Philippines, 88 pp.

Magat, S.S. 1999. Organic fertilizers in crop production, pp. 51-55. In: Benefits and Deficiencies. Coconut-Based Farming Systems, Technology Notes for Practioners. Philippine Coconut Authority, Diliman, Quezon City. ISBN No. 971-972092-1-6, 97 pp.

Magat, S.S. 1999. Management of bearing coconuts, pp.25-26. In: Production Management of Coconut (Cocos nucifera L.). Philippine Coconut Authority, Diliman, Quezon City. ISBN No. 971-92092-2-4, 67 pp.

Magat, S.S. 1996. Utilization of coconut coir dust (cocopeat) for plants: A critical review. Philippines J. Cocon. Stud. 21 (2): 63-66.

Raquepo, M.C.M. 2000. Nutrient Uptake of Chrysanthemum Roots (C. morifolium) Using Coconut Coir Dust Potting Medium. Unpublished Master of Science in Chemistry Thesis. Adamson University, San Marcelino St., Ermita. Manila, Philippines, 55 pp.

Raquepo, M.C.M. and Pabustan, C.D. 2003. A Summary of Analytical Methods for Plant, Soil, Fertilizer and Water: A Quick Reference. Unpublished Manual. Plant and Soil Analysis Division, Plant Tissue Analysis Laboratory, Agricultural Research Management Department, R, D \& E Branch, Philippine Coconut Authority, Diliman, Quezon City, Philippines, 18 pp.

Regeling Handels Potgronden (RHP), Foundation. 1997. Information on Coir. Reference Nr/Ws/MB/U.96.062 Holland, 11 pp. 
CORD Vol. XX No.2, 2004 